\title{
Dietary patterns and breast or lung cancer risk: A pooled analysis of 2 case-control studies in north-eastern Poland
}

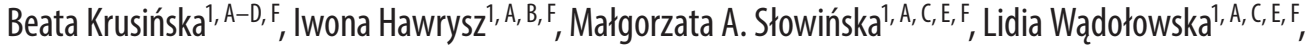 \\ Maciej Biernacki2, B, F, Anna Czerwińska ${ }^{3, B}$, F, Janusz J. Gołota ${ }^{4, B, F}$ \\ ${ }^{1}$ Department of Human Nutrition, University of Warmia and Mazury in Olsztyn, Poland \\ ${ }^{2}$ Department of Surgery, University of Warmia and Mazury in Olsztyn, Poland \\ ${ }^{3}$ Independent Public Complex of Tuberculosis and Lung Diseases in Olsztyn, Poland \\ ${ }^{4}$ Clinic of Thoracic Surgery, Ars Medica Medical Center, Olsztyn, Poland \\ A - research concept and design; $\mathrm{B}$ - collection and/or assembly of data; $\mathrm{C}$ - data analysis and interpretation; \\ $\mathrm{D}$ - writing the article; $\mathrm{E}$ - critical revision of the article; $\mathrm{F}$ - final approval of the article
}

\author{
Address for correspondence \\ Beata Krusińska \\ E-mail: beata.krusinska@uwm.edu.pl \\ Funding sources \\ None declared \\ Conflict of interest \\ None declared

\section{Acknowledgements} \\ Thanks are expressed to the participants \\ for their contribution to the study.
}

Received on February 24, 2016

Reviewed on September 16, 2016

Accepted on September 29, 2016
DOI

10.17219/acem/65433

\section{Copyright}

Copyright by Author(s)

This is an article distributed under the terms of the

Creative Commons Attribution Non-Commercial License

(http://creativecommons.org/licenses/by-nc-nd/4.0/)

\section{Abstract}

Background. Breast cancer in women and lung cancer in men are the most prevalent cancers in Poland and worldwide. Evidence of the impact of food groups and nutrients on the risk of breast and lung cancer is limited and lacking conclusions. Studies on food consumption and breast or lung cancer are limited.

Objectives. Assessment of the association between dietary patterns and the prevalence of breast and lung cancers in adult Poles.

Material and methods. The study involved a pooled analysis of 2 case-control studies on 320 subjects aged 50-70 years from north-eastern Poland (160 women, 160 men). Breast cancer cases in 80 women and lung cancer cases in 80 men were diagnosed. The food consumption frequency for 21 selected foods was collected using the Questionnaire of Eating Behaviors (QEB). Principal component analysis and multiple logistic regression analysis were used. The odds ratio (OR) and 95\% confidence interval (95\% CI) were calculated.

Results. Three dietary patterns (DPs) were identified: 'Prudent', 'Processed \& fast food', and 'Traditional Polish'. In the pooled analysis for both cancers, the ORs were from $0.35(95 \% \mathrm{Cl}: 0.20-0.61 ; \mathrm{p}<0.05$ with adjustment for age) to 0.48 ( $95 \%$ Cl: $0.26-0.88 ; p<0.05$ with adjustment for age, socioeconomic status index, physical activity, smoking, and abuse of alcohol) in the upper tertile of the 'Prudent' DP in comparison to the absence of cancers (OR $=1.00$ ). The ORs of both cancers were $1.83(95 \% \mathrm{Cl}: 1.06-3.16 ; \mathrm{p}<0.05$ with adjustment for age) in the upper tertile of the 'Processed \& fast food' DP. The ORs of both cancers for the 'Traditional Polish' DP were insignificant.

Conclusions. In the pooled analysis, a strong inverse relation was found between the 'Prudent' dietary pattern, characterized by higher frequency of dairy, fruit, vegetables, wholemeal bread, fish and juices consumption, and breast or lung cancer prevalence, irrespective of age, socioeconomic status, physical activity, smoking, alcohol abuse, and type of cancer in Polish adults from north-eastern Poland.

Key words: lung cancer, adults, breast cancer, PCA, dietary patterns 


\section{Introduction}

In industrialized countries, cancers are the second leading cause of death in humans, just after cardiovascular diseases. ${ }^{1}$ Breast cancer in women and lung cancer in men are the most prevalent cancers in Poland and worldwide. ${ }^{1}$ In Poland, in 2010, breast cancer accounted for $22 \%$ of all diagnosed cancers in women and lung cancer accounted for $21 \%$ of all cancers in men. ${ }^{2}$ Out of the 16 regions in Poland, Warmia and Mazury had the highest incidence of lung cancer in men and was $6^{\text {th }}$ in terms of the incidence of breast cancer in women in $2010 .^{2}$ The highest lung cancer mortality was recorded in men aged over 50 years old, while $50 \%$ of cases occurred after 65 years of age. ${ }^{2}$ The highest mortality of breast cancer in women was recorded in periand postmenopause, at the age of 50-69 years. ${ }^{2}$ Recently, an increase has been observed in the incidence of breast cancer in women aged 20-49 years. In Poland, the number of cases of breast cancer per 100,000 women increased from 20 in 1980 to 34 in $2010 .^{2}$

The development of cancer in the human body depends on the interactions between the immune system, individual genetic predisposition and outside environmental factors. ${ }^{3}$ From among the modifiable environmental factors, lifestyle is very important, including nutrition and quality of food consumed, as well as the degree of environmental pollution, region of residence and related social and cultural conditions. ${ }^{1,4}$ It is estimated that the role played by diet in cancer development, depending on the location, may be at the level of $10-70 \% .{ }^{3}$ Convincing evidence has only been obtained for alcoholic drinks as a factor increasing the risk of breast cancer and for beta-carotene supplements for smokers as a factor increasing the risk of lung cancer. ${ }^{1,5}$ Fruit and food containing carotenoids probably decrease the risk of lung cancer. ${ }^{1}$ There is limited evidence suggesting that nonstarchy vegetables, foods containing selenium and quercetin decrease, while red meat, processed meat, total fat, butter and retinol supplements (for smokers only) increase the risk of lung cancer. ${ }^{1}$ Evidence of the impact of other food groups and nutrients on the risk of breast and lung cancer is limited, and no conclusions have yet been drawn., ${ }^{1,5}$

Because of the complex character of the daily diet, apart from estimating the impact of the consumption of individual food groups or nutrients on cancer incidence, it is important to assess food consumption comprehensively. One of the generally accepted ways of assessing the type of most commonly consumed foods is by identifying dietary patterns. ${ }^{6}$ Currently, there are no conclusive results of research on the effects of nutrition and dietary patterns on the prevalence of breast and lung cancers, especially among Polish research in a regional perspective. Knowledge of nutritional factors associated with the risk of cancer growth is very important, both in primary and secondary prevention of cancer diseases. The similar epigenetic mechanisms of breast and lung cancers indicate common dietary causes. ${ }^{7}$
To provide a more precise evaluation of the association between dietary patterns and the prevalence of breast and lung cancers in adult Poles, a pooled analysis of 2 casecontrol studies in north-eastern Poland was performed.

\section{Material and methods}

\section{Ethical considerations}

These studies were approved by the Bioethics Committee of the Faculty of Medical Sciences, University of Warmia and Mazury in Olsztyn (Poland), on October 2, 2013 (resolution No. 29/2013). All participants gave their voluntary and written consent to take part in the studies and were informed that the information obtained was confidential and used only for scientific purposes.

\section{Study design and sample characteristics}

These studies were conducted in years 2013-2015 among adults from the Warmia and Mazury region in north-eastern Poland. The main inclusion and exclusion criteria of the sample collection and study design are shown in Fig. 1. All subjects had current results (obtained not earlier than 6 months before inclusion in the study) of ultrasonography (USG) and/or mammography of the breast (in women), and of a digital X-ray examination (RTG) and/or a computer tomography and/or bronchoscopy of the chest (in men). Subjects with breast or lung cancer, confirmed by a biopsy and/or histopathology, were included in the cancer sample (160 patients, including 80 women and 80 men, aged $50-70$ years), and those without cancer were included in the control sample (160 patients, including 80 women and 80 men, aged $50-70$ years). The control sample was matched in size, age and gender to the cancer sample. The 15 cases of nonmalignant breast cancer in women were excluded (Fig. 1). In the end, the cancer-control sample involved 320 subjects, aged $50-70$ years $(61.2 \pm 4.7)$. The characteristics of the cancer and control samples are shown in Table 1.

The cancer and control samples were chosen in a nonrandom and convenient selection. Patients with breast cancer were recruited at the surgical oncology ward of the Ministry of Internal Affairs Hospital with the Warmia and Mazury Oncology Center in Olsztyn. Patients with lung cancer were recruited at the pulmonary and oncology hospital wards in the Independent Public Complex of Tuberculosis and Lung Diseases in Olsztyn. The control sample consisted of women who came for breast screening at the Center for Prevention and Breast Diagnostics in Olsztyn, and men who came for lung screening at selected health clinics in the Warmia and Mazury region. All participants were informed of the study aim and signed the consent form to participate in the study. 


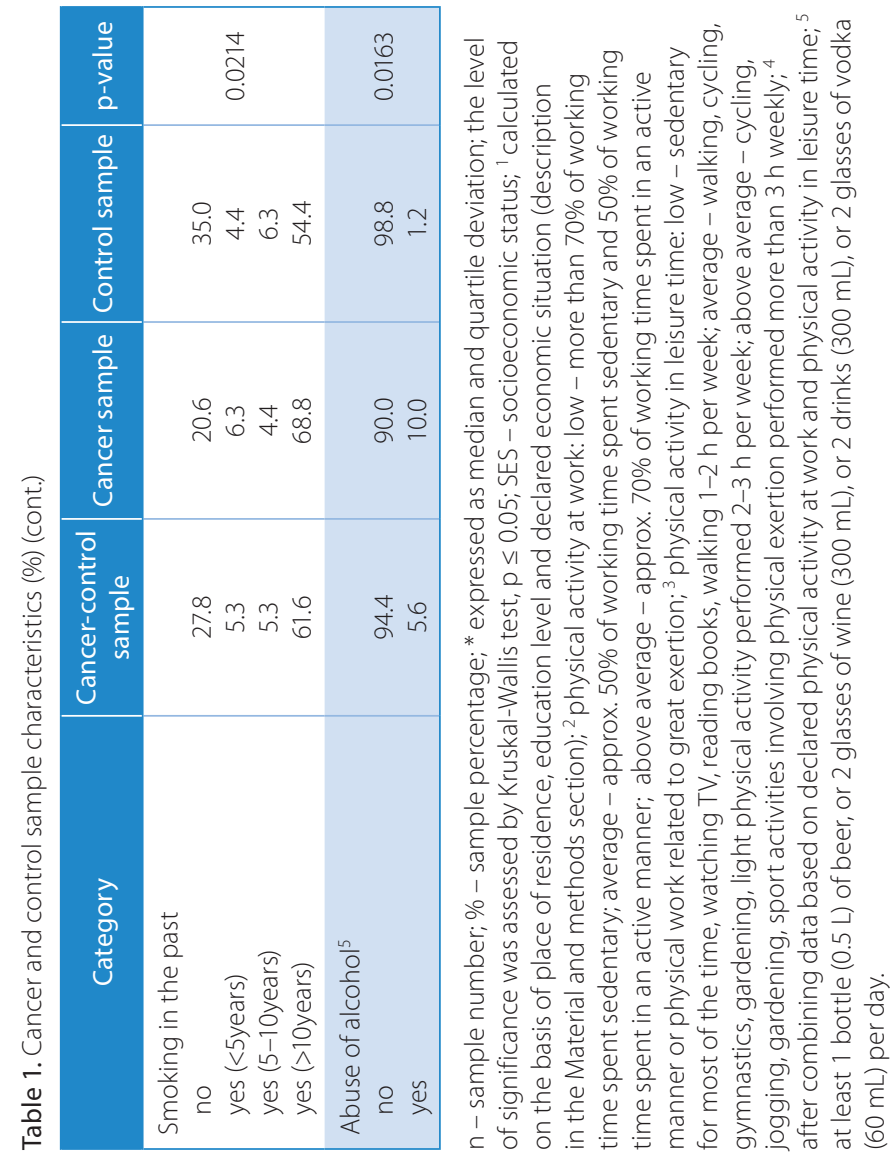

\begin{tabular}{|c|c|c|c|c|c|c|c|c|c|c|c|}
\hline 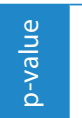 & 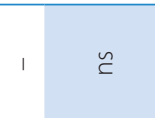 & $\frac{m}{\bar{m}}$ & 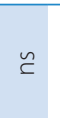 & $\check{c}$ & $\begin{array}{l}\tilde{8} \\
8 \\
0\end{array}$ & $\begin{array}{l}\hat{0} \\
\delta \\
0 \\
0\end{array}$ & $\begin{array}{l}\text { ôे } \\
\text { Oे } \\
0\end{array}$ & Бे & $\begin{array}{l}\text { nू } \\
\text { ò } \\
0 \\
0\end{array}$ & $\begin{array}{l}\bar{\delta} \\
\stackrel{\circ}{\circ} \\
\dot{v}\end{array}$ & $\check{\varepsilon}$ \\
\hline$\frac{0}{9}$ & 요요 & $\begin{array}{l}0 \\
\stackrel{+}{+1} \\
+1 \\
\stackrel{0}{0} \\
\dot{0}\end{array}$ & 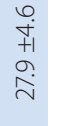 & 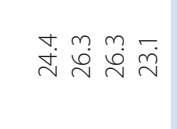 & 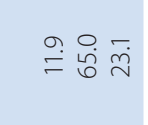 & $\bar{m} \stackrel{m}{i} \stackrel{0}{\stackrel{0}{i}}$ & 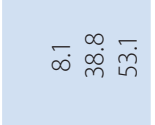 & 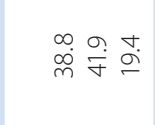 & 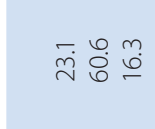 & 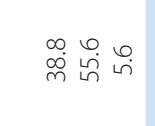 & ơ. \\
\hline 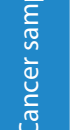 & 웅요 & $\begin{array}{l}\infty \\
\stackrel{0}{+} \\
+1 \\
\infty \\
\dot{0} \\
\dot{0}\end{array}$ & $\begin{array}{l}\bar{i} \\
+1 \\
0 \\
\stackrel{\sim}{\sim} \\
\end{array}$ & $\stackrel{\circ}{m} \underset{\sim}{\stackrel{n}{\sim}} \stackrel{m}{\sim} \stackrel{m}{\sim}$ & $\stackrel{n}{\sim} \underset{m}{\varpi} \stackrel{m}{=}$ & $\begin{array}{l}\bar{\gamma} \dot{\theta} \\
\dot{b}\end{array}$ & 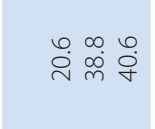 & 吕 & $\stackrel{m}{\dot{m}} \bar{\emptyset} \bar{\infty}$ & 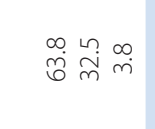 & $\begin{array}{ll}0 \\
:\end{array}$ \\
\hline 列 & in i⿱ & $\begin{array}{l}\text { P } \\
\text { +1 } \\
\text { i } \\
\end{array}$ & 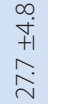 & 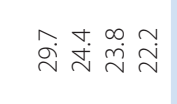 & $\hat{\sigma} \overline{\dot{\theta}} \stackrel{̃}{I}$ & 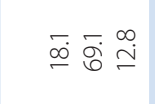 & 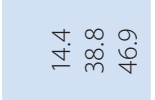 & 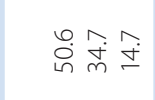 & ô & $\stackrel{m}{i n} \bar{f} f$ & 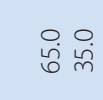 \\
\hline & 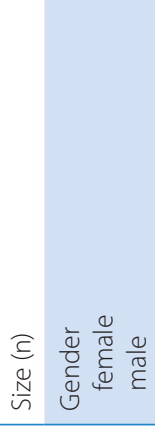 & 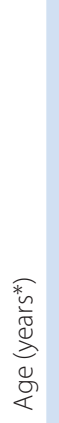 & 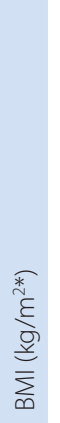 & 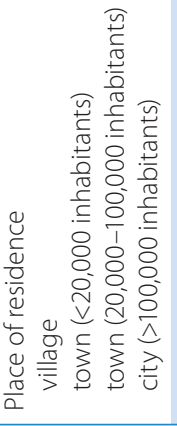 & 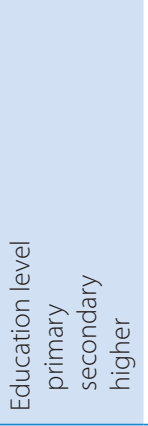 & 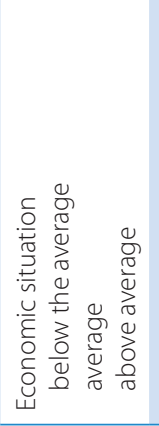 & 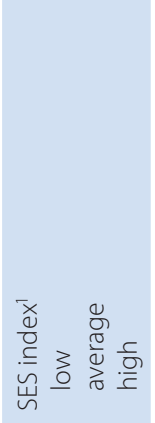 & 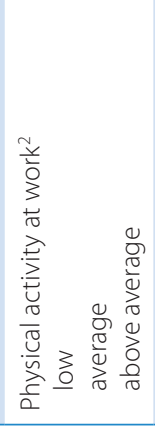 & 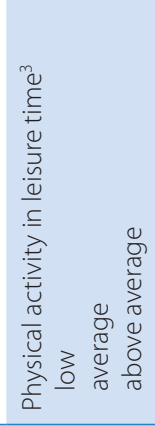 & 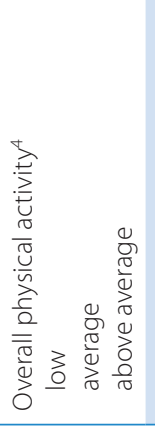 & 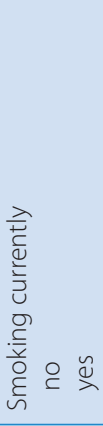 \\
\hline
\end{tabular}




\section{Food frequency}

Information on the consumption of selected 21 food groups (Table 2) in the last 12 months before involvement in this study was obtained by the food frequency method, using an interviewer-administrated QEB questionnaire (Questionnaire of Eating Behaviors) of great internal reliability with Fleiss' kappa from 0.64 to $0.84 .^{8,9}$ The frequency of consumption was expressed in 6 categories: never, 1-3 times per month, once per week, several times per week, daily, several times per day. The frequency of consumption was then expressed as times/day and assigned the following values: never $=0 ; 1-3$ times per month $=0.06$; once per week $=0.14$; several times per week $=0.5$; daily $=1$; several times per day $=2$.

\section{Confounders}

Respondents were asked about 3 single factors of their socioeconomic status (SES). Numerical values were assigned to each response category as follows (in brackets):

- place of residence: village (1), town with $<20,000$ inhabitants (2), town with 20,000-100,000 inhabitants (3), city with $>100,000$ inhabitants (4);

- educational level: primary (1), secondary (2), higher (3);

- economic status (self-declared): below average (1), average (2), above average (3).

The SES index was calculated as the sum of the values assigned to the individual response categories to each SES factor. The SES index values were logarithmized, and then

\begin{tabular}{|c|}
\hline \begin{tabular}{ll} 
& \multicolumn{1}{c}{ Inclusion criteria } \\
- & gender (men, women) \\
- & age ( $50-70$ years) \\
- & place of residence \\
- & norban and rural areas) \\
no dietary changes for the \\
last 10 years
\end{tabular} \\
\hline
\end{tabular}

\begin{tabular}{l} 
Inclusion criteria \\
diagnosed cases \\
of breast \\
(women)/lung \\
cancer (men) \\
\hline
\end{tabular}

\begin{tabular}{|l|}
\hline \multicolumn{1}{|c|}{ Excluding } \\
15 cases of non- \\
malignant breast \\
cancer (women)
\end{tabular}
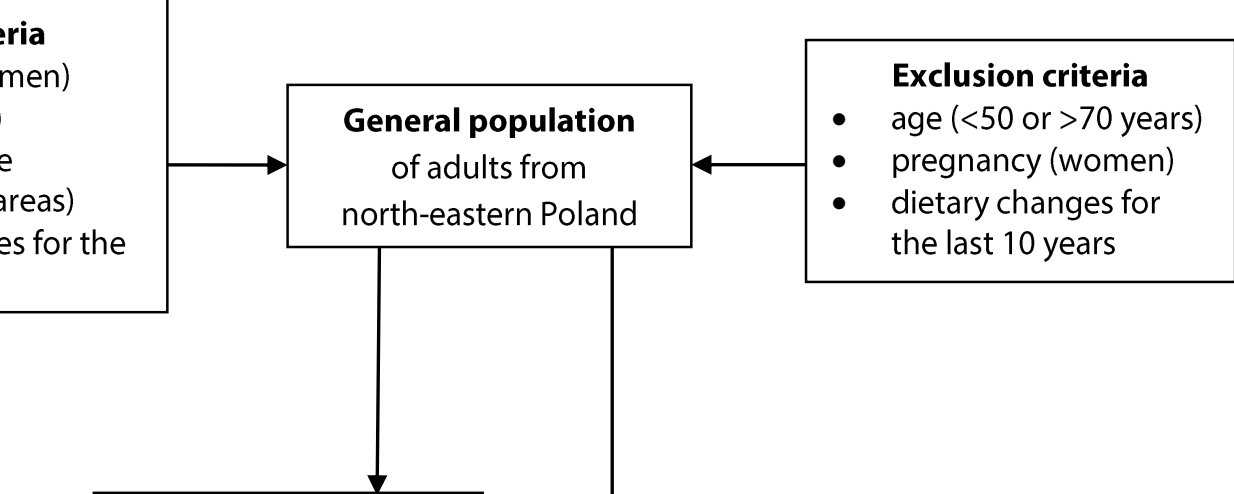

Matching sample

Initial Cancer sample

$\mathrm{n}=175$ patients

(95 woman, 80 men)

(size, age, gender)
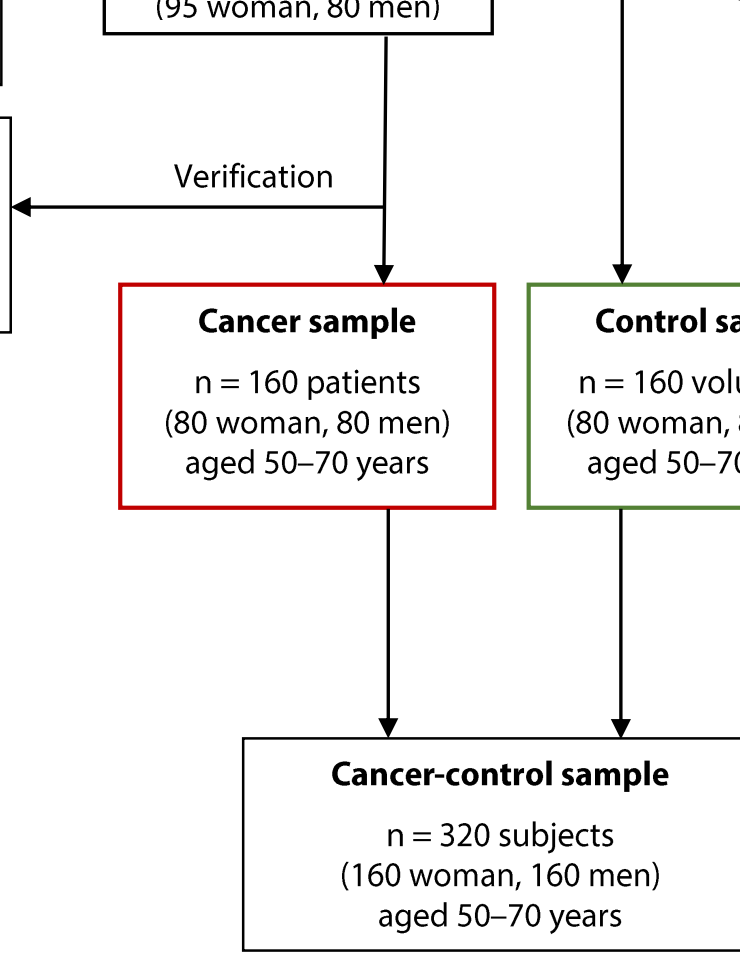

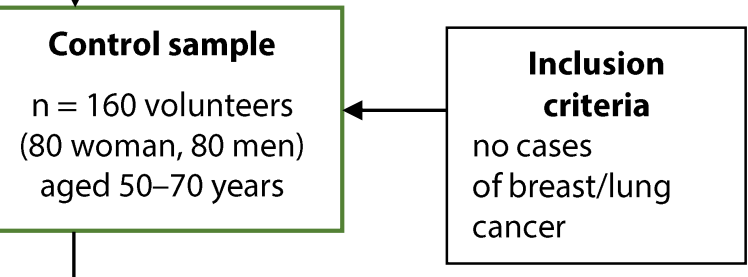

Fig. 1. Flow chart of sample collection and study design 
the tertiles of the SES were created to identify respondents with low, average, and high SES.

Respondents were asked about their physical activity at work. Numerical values were assigned to each response category as follows (in brackets): low - more than 70\% of working time spent sedentary (1); average - approx. 50\% of working time spent sedentary and $50 \%$ of working time spent in an active manner (2); above average - approx. $70 \%$ of working time spent in an active manner or physical work related to great exertion (3). ${ }^{10}$ Respondents were also asked about their physical activity in leisure time. Numerical values were assigned to each response category as follows (in brackets): low - sedentary for most of the time, watching TV, reading books, walking $1-2 \mathrm{~h}$ per week (1); average - walking, cycling, gymnastics, gardening, light physical activity performed $2-3 \mathrm{~h}$ per week (2); above average - cycling, jogging, gardening, sport activities involving physical exertion performed more than $3 \mathrm{~h}$ weekly (3). ${ }^{10}$ The data based on the physical activity declared at work and in leisure time was combined, then 3 categories of overall physical activity were created, with

Table 2. The values of factor loadings for selected food groups in dietary patterns - PCA

\begin{tabular}{|c|c|c|c|}
\hline \multirow[b]{2}{*}{ Food groups $\#$} & \multicolumn{3}{|c|}{ Dietary Patterns } \\
\hline & 'Prudent' & $\begin{array}{l}\text { 'Processed } \\
\& \text { fast food' }\end{array}$ & $\begin{array}{l}\text { 'Traditional } \\
\text { Polish' }\end{array}$ \\
\hline Curd cheese (including homogenized cheese) & 0.67 & & \\
\hline Fermented milk drinks & 0.60 & & \\
\hline Fruit & 0.55 & & \\
\hline Wholemeal bread & 0.52 & -0.26 & -0.24 \\
\hline Vegetables & 0.47 & -0.23 & 0.37 \\
\hline Fish and fish dishes & 0.47 & & \\
\hline Cheese (including cream cheese) & 0.47 & 0.26 & 0.27 \\
\hline Milk & 0.37 & & \\
\hline Fruit, vegetable or vegetable-fruit juices & 0.36 & & 0.31 \\
\hline Soups (instant, ready to eat) & & 0.71 & \\
\hline $\begin{array}{l}\text { Canned meat, canned fish or canned } \\
\text { vegetable-meat }\end{array}$ & & 0.58 & \\
\hline Alcoholic drinks & & 0.53 & \\
\hline Fast food & & 0.48 & \\
\hline Potatoes & & & 0.65 \\
\hline Sweets, confectionery & & & 0.58 \\
\hline Sweetened carbonated beverages & & & 0.39 \\
\hline Meat and meat dishes & 0.21 & & 0.30 \\
\hline Fried foods & & 0.24 & 0.22 \\
\hline Canned vegetables or fruit, pickles & 0.23 & & 0.20 \\
\hline Legume-based dishes & 0.22 & & \\
\hline Energy drinks & & & -0.16 \\
\hline Share in explaining the variance (\%) & 13 & 8 & 7 \\
\hline
\end{tabular}

\# PCA was performed on standardized variables (frequency of consumption expressed as times/ day) for cancer-control sample $(n=320)$. numerical values assigned as follows (in brackets): low (1); average (2); above average (3). ${ }^{11}$

Respondents were asked about smoking currently: no (1), yes (2); smoking in the past: no (1), yes <5years (2), yes 5-10years (3), yes >10years (4); and abuse of alcohol: no (1), yes (2), defined as intake of at least 1 bottle $(0.5 \mathrm{~L})$ of beer, or 2 glasses of wine $(300 \mathrm{~mL})$, or 2 drinks $(300 \mathrm{~mL})$, or 2 glasses of vodka $(60 \mathrm{~mL})$ per day.

\section{Statistical analysis}

For the cancer-control sample, the consumption frequency (times/day) of 21 selected food groups was expressed as a mean value, and then was standardized and included in the Principal Component Analysis (PCA) with varimax rotation. ${ }^{12}$ Three dietary patterns (DPs) were identified a posteriori based on the factor loadings for standardized mean values of food consumption frequency and Scree plot for eigenvalues of factors, and the sum of explaining the variance (Fig. 1). The value $|0.3|$ was accepted as the cut-off point of factor loadings, and the tertile intervals were calculated for each of the 3 dietary patterns. We compared the percentage distribution of the prevalence of breast or lung cancer in tertiles of DPs by Pearson $\chi^{2}$ test with Yates' correction as necessary. The prevalence of breast or lung cancer as a categorical independent dichotomous variable in the upper and middle tertile in comparison to the bottom tertile of DPs was assessed. A logistic regression analysis was performed. The odds ratio (OR) and 95\% confidence interval (95\% CI) were calculated. The reference groups were subjects without cancer $(\mathrm{OR}=1.00)$ and subjects in the bottom tertile of each DPs $(O R=1.00)$. Five models were created: model 1 - without adjustment for confounding variables; model 2 - with adjustment for age as a continuous variable; model 3 - with adjustment for age and SES index; model 4 - with adjustment for age, SES index, overall physical activity, smoking in the past and abuse of alcohol; and model 5 - with adjustment for age, SES index, overall physical activity, smoking in the past, abuse of alcohol and type of cancer. The significance of the odds ratio was assessed by Wald's statistics. ${ }^{12}$ The statistical analysis was performed using STATISTICA v. 10.0 PL (StatSoft Inc., USA, Tulsa; StatSoft Polska, Kraków). A pvalue $<0.05$ was considered statistically significant. 


\section{Results}

\section{Food consumption frequency and dietary patterns}

These studies found 3 main dietary patterns. The 'Prudent' DP was positively correlated with the frequency of consumption of: curd cheese $(r=0.67)$, fermented milk drinks $(r=0.60)$, fruit $(r=0.55)$, wholemeal bread $(r=0.52)$, vegetables, fish and fish dishes, cheese $(r=0.47)$, milk ( $r=0.37)$, fruit, vegetable or vegetable-fruit juices $(\mathrm{r}=0.36)$ (Table 2). The 'Processed \& fast food' DP was positively correlated with the consumption frequency of: instant soups, concentrated ready-made soups $(\mathrm{r}=0.71)$, canned meat, fish or canned vegetable-meat $(r=0.58)$, alcoholic drinks $(\mathrm{r}=0.53)$, and fast food $(\mathrm{r}=0.48)$ (Table 2). The 'Traditional Polish' DP was positively correlated with the frequency of consumption of: potatoes $(r=0.65)$, sweets $(r=0.58)$, sweetened carbonated beverages $(r=0.39)$, meat and meat dishes $(r=0.30)$ (Table 2$)$. The shares in explaining the variance for 'Prudent', 'Processed \& fast food' and 'Traditional Polish' DPs were 13\%, $8 \%$ and $7 \%$, respectively (Table 2 ).

\section{Dietary patterns and breast or lung cancer prevalence}

There was a statistically significant decrease of the percentage of breast or lung cancer cases in tertiles of the 'Prudent' DP ( $p=0.0010)$ (Table 3). In the upper tertile

Table 3. Dietary patterns and the prevalence of breast or lung cancer

\begin{tabular}{|c|c|c|c|c|c|}
\hline \multirow{3}{*}{ Dietary patterns } & \multicolumn{4}{|c|}{ Cancer (\% of the sample) } & \multirow{3}{*}{$p$-trend } \\
\hline & \multicolumn{3}{|c|}{ tertiles of dietary patterns } & \multirow{2}{*}{$p$-value } & \\
\hline & bottom & middle & upper & & \\
\hline $\begin{array}{l}1 \text { - 'Prudent' } \\
\text { (curd cheese, fermented milk drinks, fruit, wholemeal bread, } \\
\text { vegetables, fish and fish dishes, cheese, milk, fruit/vegetable/ } \\
\text { vegetable-fruit juices) }\end{array}$ & $\begin{array}{c}(n=106) \\
41.3^{a}\end{array}$ & $\begin{array}{c}(n=108) \\
34.4\end{array}$ & $\begin{array}{c}(n=106) \\
24.4^{a}\end{array}$ & 0.0010 & ns \\
\hline $\begin{array}{l}2 \text { - 'Processed\&fast food' } \\
\text { (instant soups/concentrated, ready-made soups, canned meat/ } \\
\text { fish/vegetable-meat, alcoholic drinks, fast food) }\end{array}$ & $\begin{array}{c}(n=107) \\
28.8\end{array}$ & $\begin{array}{c}(n=106) \\
32.5\end{array}$ & $\begin{array}{c}(n=107) \\
38.8\end{array}$ & ns & ns \\
\hline $\begin{array}{l}3 \text { - 'Traditional Polish' } \\
\text { (potatoes, sweets, sweetened carbonated beverages, meat } \\
\text { and meat dishes) }\end{array}$ & $\begin{array}{c}(n=106) \\
33.8\end{array}$ & $\begin{array}{c}(n=108) \\
35.6\end{array}$ & $\begin{array}{c}(n=106) \\
30.6\end{array}$ & ns & ns \\
\hline
\end{tabular}

$\mathrm{n}$ - sample size; $\mathrm{ns}$ - the differences were not statistically significant (the level of significance was assessed by Pearson's $x^{2}$ test, $p \leq 0.05$ ); ${ }^{a}$ statistically significant differences between the pairs of dietary pattern tertiles, $p \leq 0.05$.

Table 4. Odds ratio (OR) and 95\% confidence interval $(95 \% \mathrm{Cl})$ of breast or lung cancer prevalence in relation to dietary patterns

\begin{tabular}{|c|c|c|c|c|c|c|}
\hline \multirow{3}{*}{$\begin{array}{c}\text { Dietary } \\
\text { patterns }\end{array}$} & \multicolumn{6}{|c|}{ OR $(95 \% \mathrm{Cl})$} \\
\hline & \multirow{2}{*}{$\begin{array}{l}\text { without } \\
\text { cancer } \\
(n=160)\end{array}$} & \multicolumn{5}{|c|}{ cancer $(n=160)$} \\
\hline & & model 1 & model 2 & model 3 & model 4 & model 5 \\
\hline \multicolumn{7}{|c|}{1 - 'Prudent' } \\
\hline bottom tertile & 1.00 & 1.00 & 1.00 & 1.00 & 1.00 & 1.00 \\
\hline middle tertile & 1.00 & $0.63(0.36-1.09)$ & $0.59(0.34-1.04)$ & $0.60(0.34-1.05)$ & $0.70(0.39-1.27)$ & $0.64(0.35-1.16)$ \\
\hline upper tertile & 1.00 & $0.35^{* * *}(0.20-0.62)$ & $0.35^{* * *}(0.20-0.61)$ & $0.38^{* * *}(0.21-0.66)$ & $0.48^{*}(0.26-0.88)$ & $0.41^{* *}(0.22-0.78)$ \\
\hline \multicolumn{7}{|c|}{$2-$ - 'Processed \& fast-food' } \\
\hline bottom tertile & 1.00 & 1.00 & 1.00 & 1.00 & 1.00 & 1.00 \\
\hline middle tertile & 1.00 & $1.28(0.74-2.20)$ & $1.29(0.74-2.25)$ & $1.22(0.69-2.16)$ & $1.16(0.64-2.10)$ & $1.10(0.61-1.97)$ \\
\hline upper tertile & 1.00 & $1.83 *(1.06-3.15)$ & $1.83^{*}(1.06-3.16)$ & $1.66(0.95-2.90)$ & $1.53(0.82-2.86)$ & $1.60(0.87-2.97)$ \\
\hline \multicolumn{7}{|c|}{3 - 'Traditional Polish' } \\
\hline bottom tertile & 1.00 & 1.00 & 1.00 & 1.00 & 1.00 & 1.00 \\
\hline middle tertile & 1.00 & $1.08(0.63-1.84)$ & $1.08(0.63-1.87)$ & $1.12(0.64-1.96)$ & $1.10(0.62-1.97)$ & $1.08(0.61-1.91)$ \\
\hline upper tertile & 1.00 & $0.83(0.48-1.42)$ & $0.92(0.53-1.60)$ & $0.79(0.44-1.42)$ & $0.75(0.40-1.38)$ & $0.68(0.38-1.21)$ \\
\hline
\end{tabular}

model 1 - without adjustment for confounding variables; model 2 - with adjustment for age; model 3 - with adjustment for age and SES index; model 4 - with adjustment for age, SES index, overall physical activity, smoking in the past and abuse of alcohol; model 5 - with adjustment for age, SES index, overall physical activity, smoking in the past, abuse of alcohol and type of cancer; the level of significance was assessed by Wald's test, ${ }^{*} p \leq 0.05$, ${ }^{* *} p<0.01$, *** $p<0.001$. 
of the 'Prudent' DP in comparison to the bottom tertile, there was a significantly lower percentage of breast or lung cancer cases reported (24.4\% vs $41.3 \%$ ) (Table 3 ). There were no significant differences reported in the percentage of breast or lung cancer cases within the tertiles of the 'Processed \& fast food' DP and the 'Traditional Polish' DP (Table 3).

Two out of the 3 identified dietary patterns, 'Prudent' and 'Processed \& fast food', showed a significant association with the prevalence of breast or lung cancers in a logistic regression analysis (Table 4). Subjects in the upper tertile of the 'Prudent' DP in comparison to the bottom tertile had a lower risk of breast or lung cancers, from $52 \%$ (model 4: OR = 0.48; 95\% CI: $0.26-0.88 ; \mathrm{p}<0.05)$ to $65 \%$ (model 2: OR $=0.35 ; 95 \%$ CI: $0.20-0.61 ; \mathrm{p}<0.001$ ) (Table 4). Subjects in the upper tertile of the 'Processed \& fast food' DP in comparison to the bottom tertile had almost 2-fold higher risk of breast or lung cancers (model 2: OR $=1.83 ; 95 \%$ CI: $1.06-3.16 ; \mathrm{p}<0.05)($ Table 4$)$ . There was no significant association reported between the 'Traditional Polish' DP and the risk of breast or lung cancers (Table 4).

\section{Discussion}

This work presents the results of the first study on dietary patterns and breast or lung cancer prevalence in Poland. We found a strong inverse association between the 'Prudent' DP and the prevalence of breast or lung cancer cases, irrespective of age, socioeconomic status, physical activity, smoking, abuse of alcohol, and type of cancer as confounding variables. Inversely, the 'Processed \& fast food' DP was weakly associated with an increased risk of breast or lung cancers. There was no evidence of an association between the 'Traditional Polish' DP and the prevalence of breast or lung cancer in female and male adults from north-eastern Poland.

In the study, the 'Prudent' DP was characterized by a high frequency of consumption of dairy products, fruit, vegetables, wholemeal bread, fish and juices, and significantly reduced risk of breast or lung cancer (from $52 \%$ to $65 \%$, depending on confounders incorporated into the model). A similar trend has been observed in studies conducted in many countries around the world. However, not all studies adjusted the results for the many confounders such as alcohol consumption, smoking or physical activity, as in our study. The DPs characterized by high consumption of fruit and vegetables, such as 'Plant-based', 'Fruit and salad' and 'Antioxidants', were associated with a $15-56 \%$ lower risk of breast cancer in women and with a $39 \%$ lower risk of lung cancer in men. ${ }^{13-15}$ In a systematic review, in 10 out of 26 studies, a significant association was found between the 'Mediterranean' DP, comprised of vegetables, fruit, legumes, fish and olive oil, and a reduced risk of breast cancer in women on vari- ous continents (from $27 \%$ to $86 \%$ ). ${ }^{16}$ In a meta-analysis, in a combination of 8 case-control and 10 cohort studies, it was shown that the 'Prudent/Healthy' DP, rich in fruit, vegetables, poultry, fish, low-fat dairy and whole grains, reduced the risk of breast cancer by $11 \% .{ }^{17}$ In the Netherlands Cohort Study, the 'Salad vegetables' DP, comprised of vegetables, fruit, pasta, rice, poultry, fish and oil, reduced the risk of lung cancer by $25 \%{ }^{18}$ This protective effect probably resulted from a high-quality diet, rich in bioactive compounds including specific peptides, fatty acids, phenolics, vitamins, minerals and fiber. Conversely, in a North American study, the 'Prudent' DP, comprised of low-fat dairy products, whole grains, vegetables, fruit, legumes and vegetable or fruit juices, increased the risk of breast cancer 1.42 times. ${ }^{19}$ This result is contrary to conventional wisdom and to the results of other studies. In the USA, the 'Prudent' DP diet is relatively higher in carbohydrates and fat than the diet of 'Prudent/ Healthy' DPs in European countries. In some studies, there was no association found between breast cancer risk and the 'Cereals/Milk/Dairy' DP, 'Vegetable' DP and 'Prudent' DP rich in low-fat dairy products, juices, whole grains, vegetables and fruit. ${ }^{13,20,21}$ The differences in these associations could result from differences in the study designs, study populations, secular trends in food supply or different definitions of 'Prudent/Healthy' diet and characteristics for their foods. ${ }^{19}$

In these studies, the 'Processed \& fast food' DP was characterized by a higher frequency of consumption of alcoholic drinks and processed food such as fast food, instant soups and canned goods, which increased the risk of breast or lung cancers almost 2 times, but this relation was weaker and disappeared after the adjustment for many confounders. Many studies performed in different countries such as Germany, Italy and Korea, did not report a statistically significant association between the 'Western' DP and breast cancer. ${ }^{22-24}$ However, the 'Drinkers' DPs, including alcoholic beverages such as wines, beers and spirits, were associated with increased risk of breast cancer, from $12 \%$ in the California Teachers' Study, through $21 \%$ in a meta-analysis of 4 studies and $40 \%$ in Uruguayan women, to 2.5 times in French women. ${ }^{13,17,25,26}$ Alcohol is a proven risk factor for breast cancer. ${ }^{1}$ The 'Western/Unhealthy' DPs, which were characterized by a high consumption of processed meat, fast food, canned goods, mayonnaise, butter, high-fat dairy, refined grains, sweets and alcoholic beverages, increased the risk of breast cancer from $20 \%$ in the French Cohort Study to $31 \%$ in a meta-analysis. ${ }^{17,27}$ In a Spanish study, the 'High-meat' DP, rich in processed meat, fried red meat and alcoholic beverages, increased the risk of breast cancer approx. 3.5 times. ${ }^{21}$ In the Netherlands Cohort Study, the 'pork, processed meat and potatoes' DP increased the risk of lung cancer 2.67 times. ${ }^{18}$ However, this negative effect probably resulted from a diet rich in foods with high energy density, with high glycemic index (GI) or glycemic 
load (GL) such as processed food, because of their high fat and sugar content. ${ }^{28}$ The differences in associations could result, as mentioned above, from differences in the study designs, study populations, trends in food supply or different definitions of 'Western/Unhealthy' diet and characteristics of their food. ${ }^{19}$

In our studies, the 'Traditional Polish' DP was characterized by a higher frequency of potatoes, sweets, beverages, and meat consumption, mainly as fried foods, which are typical foods in the Polish diet. There was no significant effect found for the 'Traditional Polish' DP on the prevalence of breast or lung cancers in Polish adults from north-eastern Poland. The 'Traditional Polish' DP included both food with potentially beneficial effects on health such as potatoes, and food with potentially negatively effects on health such as fried meat, sweets and sweetened carbonated beverages, which may determine its neutral character in relation to the prevalence of cancer cases. As in our studies, in many studies there was no evidence of an association between 'Traditional' DP and risk of breast or lung cancers. Dietary patterns such as the Australian 'Meat' (meat, fried dishes, cooked potatoes and pickled vegetables), the Greek 'Meat/Potatoes', the Californian 'High-protein' (meat, fried foods and fat), and the 'Ethnic' (legumes, soy-based foods, rice and leafy vegetables) were not significantly associated with breast cancer risk. ${ }^{13,14,20}$ To the contrary, in Asian-American women, the 'Ethnic meat/starch' DP, comprised of vegetable soups, pork, dried and salted fish and fried rice, increased the risk of breast cancer almost 1.5 times. ${ }^{29}$ Among Uruguayan men, the 'High-meat' DP, characterised by high consumption of meat, dairy products, eggs and desserts, increased the risk of lung cancer about 3 times. ${ }^{15}$ Some of the 'Traditional' DPs decreased the risk of breast cancer, from $22 \%$ for the 'Traditional southern US' (cooked greens, beans, legumes, mixed vegetables, fried fish and chicken) to $47 \%$ for the 'Uruguayan' (cooked red meat, cereals, cooked legumes and tubers). ${ }^{30,31}$ Differences in associations between the 'Traditional' DPs and the prevalence of breast or lung cancers could result from the different characteristics of the typical foods in the diet of a given country/region.

The present study provides new and interesting insights regarding dietary patterns and breast or lung cancer risk. It was found that the protective effect of a diet composed of dairy, fruit, vegetables, wholemeal bread, fish and juices was stronger than the negative effects of a diet containing alcoholic drinks and processed food on cancer prevalence. This effect did not depend upon the presence of many confounders, which included age, socioeconomic status, physical activity, abuse of alcohol, smoking, and type of cancer. It may be supposed that a regular diet composed of dairy, fruit, vegetables, wholemeal bread, fish and juices may reduce the negative effects of the socioeconomic and lifestyle risk factors of cancer. Furthermore, we found this diet composition using a data-driven approach by drawing dietary patterns from a data-set. ${ }^{12,32}$ So, there is strong evidence that such dietary patterns exist in real life and may be found within Polish adults from north-eastern Poland. It is also possible that similar dietary patterns may be found among other people living in central and eastern Europe. ${ }^{33}$ Thus, our results may go beyond national significance. Finally, these findings may be helpful in making public dietary recommendations when improving strategies to promote a healthy diet and decrease the risk of breast and lung cancer.

\section{Study strengths and weaknesses}

The major weakness of these studies is a lack of quantitative data regarding food and nutrient intake. However, current evidence shows the limitations of a single-nutrient component focus. ${ }^{32}$ We collected data concerning the frequency of food consumption, which reflected the usual intake, and then identified the dietary patterns. Dietary patterns represent the overall combination of foods usually consumed, which together produce synergistic health effects. ${ }^{32}$ The strength of the study was that we used the validated, interviewer-administrated FFQ of greater internal repeatability than the self-administrated FFQ. ${ }^{9}$ Moreover, the prevalence of cancer incidence was confirmed by histopathology results. These studies were interdisciplinary studies including 2 scientific areas: human nutrition and medicine - oncology, which is rare in Polish studies. An interesting area of these studies was to show the dietary patterns and prevalence of breast and lung cancers in a pooled analysis across a wide area of north-eastern Poland.

\section{Conclusions}

There was a strong inverse relation between the 'Prudent' dietary pattern and breast or lung cancer prevalence, irrespective of age, socioeconomic status, physical activity, smoking, alcohol abuse or type of cancer in Polish adults from north-eastern Poland. For cancer prevention, one should start a diet composed of dairy products, fruit, vegetables, wholemeal bread, fish and juices. Our approach is focused on the foods and overall dietary patterns that exist in the real life of people living in north-eastern Poland, not on single isolated nutrients. So, this food-based approach is better fitted to making public dietary recommendations and individual behavioural counseling.

\section{References}

1. World Cancer Research Fund, American Institute for Cancer Research. Food, Nutrition, Physical Activity, and the Prevention of Cancer: A Global Perspective. Washington, DC: American Institute for Cancer Research; 2007.

2. Wojciechowska U, Didkowska J, Zatoński W. Nowotwory złośliwe w Polsce w 2010 roku [Cancer in Poland in 2010]. http://onkologia.org.pl/wpcontent/uploads/Nowotwory_2010.pdf. Accessed June 10, 2015.

3. Jarosz M. Nowotwory złośliwe. Jak zmniejszyć ryzyko zachorowania? Warszawa: Wydawnictwo lekarskie PZWL; 2008. 
4. Vineis P, Wild CP. Global cancer patterns: Causes and prevention. Lancet. 2014;383:549-557.

5. World Cancer Research Fund, American Institute for Cancer Research Continuous Update Project. Keeping the science current. Breast Cancer 2010 Report. Food, Nutrition, Physical Activity, and the Prevention of Breast Cancer. Washington, DC: American Institute for Cancer Research; 2010.

6. Wądołowska L. Zasady obliczania i interpretacji wyników. In: Gronowska-Senger A, ed. Przewodnik metodyczny badań sposobu żywienia. Warszawa: Komitet Nauki o Żywieniu Człowieka Polskiej Akademii Nauk; 2013:38-65.

7. Xu S, Wang P, You Z, et al. The long non-coding RNA EPB41L4AAS2 inhibits tumor proliferation and is associated with favorable prognoses in breast cancer and other solid tumors. Oncotarget. 2016;15:20704-20717.

8. Wądołowska L, Krusińska B. Procedura opracowania danych żywieniowych z kwestionariusza QEB. http://www.uwm.edu.pl/edu/lidiawadolowska. Accessed May 5, 2015.

9. Kowalkowska J, Wądołowska L, Czarnocińska J, et al. Analiza zgod ności wewnętrznej „Kwestionariusza do badania zachowań żywieniowych i opinii na temat żywności i żywienia" QEB. http://www. uwm.edu.pl/edu/lidiawadolowska. Accessed June 20, 2016.

10. Jarosz M, Taraszewska A. Nadwaga i otyłość oraz wybrane elementy stylu życia jako czynniki ryzyka GERD. Post Nauk Med. 2011;9:749-759.

11. Wądołowska L, Krusińska B. Procedura opracowania danych żywieniowych z kwestionariusza KomPAN. In: Gawęcki J, ed. Kwestionariusz do badania poglądów i zwyczajów żywieniowych oraz procedura opracowania danych. Warszawa: Zespół Behawioralnych Uwarunkowań Żywienia, Komitet Nauki o Żywieniu Człowieka Polskiej Akademii Nauk; 2014:34-51. http://www.knozc.pan.pl/. Accessed May 20, 2016.

12. Wirfält $E$, Drake I, Wallström P. What do review papers conclude about food and dietary patterns? Food Nutr Res. 2013;57. doi: 10.3402/fnr.v57i0.20523

13. Link LB, Canchola AJ, Bernstein L, et al. Dietary patterns and breast cancer risk in the California Teachers Study cohort. Am J Clin Nutr. 2013;98:1524-1532.

14. Baglietto L, Krishnan K, Severi G, et al. Dietary patterns and risk of breast cancer. Br J Cancer 2011;104:524-531.

15. De Stefani E, Boffettab $P$, Roncoc $A L$, et al. Nutrient patterns and risk of lung cancer: NA factor analysis in Uruguayan men. Lung Cancer. 2008;61:283-291.

16. Albuquerque RCR, Baltar VT, Marchioni DML. Breast cancer and dietary patterns: A systematic review. Nutr Rev. 2013;72:1-17.

17. Brennan SF, Cantwell MM, Cardwell CR, Velentzis LS, Woodside JV. Dietary patterns and breast cancer risk: A systematic review and meta-analysis. Am J Clin Nutr. 2010;91:1294-1302.

18. Balder HF, Goldbohm RA, van den Brandt PA. Dietary patterns associated with male lung cancer risk in the Netherlands Cohort Study. Cancer Epidemiol Biomarkers Prev. 2005;14:483-490.

19. Murtaugh MA, Sweeney C, Giuliano AR, et al. Diet patterns and breas cancer risk in Hispanic and non-Hispanic white women: The FourCorners Breast Cancer Study. Am J Clin Nutr. 2008;87:978-984.

20. Demetriou CA, Hadjisavvas A, Loizidou MA, et al. The mediterranean dietary pattern and breast cancer risk in Greek-Cypriot women: A case control study. BMC Cancer. 2012;12:113-124.

21. Castello A, Polla M, Buijsse B, et al. Spanish Mediterranean diet and other dietary patterns and breast cancer risk: Case-control EpiGEICAM study. Br J Cancer. 2014;111:1454-1462.

22. Buck K, Vrieling A, Flesch-Janys D, et al. Dietary patterns and the risk of postmenopausal breast cancer in a German case-control study. Cancer Causes Control. 2011;22:273-282.

23. Sant M, Allemani C, Sieri S, et al. Salad vegetables dietary patterns protects against HER-2-positive cancer: A prospective Italian study. Int J Cancer. 2007;121:911-914.

24. Cho YA, Kim J, Shin A, et al. Dietary patterns and breast cancer risk in Korea women. Nutr Cancer. 2010;62:1161-1169.

25. De Stefani E, Deneo-Pellegrini H, Boffetta P, et al. Dietary patterns and risk of cancer: A factor analysis in Uruguay. Int J Cancer. 2009;124:1391-1397.

26. Bessaoud F, Tretarre B, Daures JP, et al. Identification of dietary patterns using two statistical approaches and their association with breast cancer risk: A case-control study in southern France. Ann Epidemiol. 2012;22:499-510.
27. Cottet V, Touvier M, Fournier A, et al. Postmenopausal breast cancer risk and dietary patterns in the E3N-EPIC Prospective Cohort Study. Am J Epidemiol. 2009;170:1257-1267.

28. Woo HD, Park K, Shin A, Ro J, Kim J. Glycemic index and glycemic load dietary patterns and the associated risk of breast cancer: A case-control study. Asian Pac J Cancer Prev. 2013;14:5193-5198.

29. Wu AH, Yu MC, Tseng Ch, Stanczyk FZ, Pike MC. Dietary patterns and breast cancer risk in Asian American women. Am J Clin Nutr. 2009;89:1145-1154.

30. Velie EM, Schairer C, Flood A, He J, Khattree R, Schatzkin A. Empirically derived dietary patterns and risk of postmenopausal breast cancer in a large prospective cohort study. Am J Clin Nutr. 2005;82:1308-1319.

31. Ronco $A L$, De Stefani $E$, Boffetta $P$, et al. Food patterns and risk of breast cancer: A factor analysis study in Uruguay. Int J Cancer. 2006;119:1672-1678.

32. Mozaffarian D. Dietary and policy priorities for cardiovascular disease, diabetes, and obesity: A comprehensive review. Circulation. 2016. doi: 10.1161/CIRCULATIONAHA.115.018585

33. Luksiene DI, Baceviciene M, Tamosiunas A, Daugeliene E, Kranciukaite D. Health, Alcohol and Psychosocial factors In Eastern Europe (HAPIEE) study: Dietary patterns and their association with sociodemographic factors in Lithuanian urban population of Kaunas city. Int J Public Health. 2011;56:209-216. 